\title{
Treatment with Lithium Induces a Long-Term Enhancement of Neurogenesis in the Subventricular Zone of the Ts65Dn model of Down Syndrome
}

\author{
Fiorenza Stagni, Andrea Giacomini, Marco Emili, Beatrice Uguagliati, Patrizia Bianchi, Renata Bartesaghi* and \\ Sandra Guidi \\ Department of Biomedical and Neuromotor Sciences, University of Bologna, Italy
}

Submission: February 08, 2018; Published: May 09, 2018

*Corresponding author: Renata Bartesaghi, Department of Biomedical and Neuromotor Sciences, Physiology Building, Piazza di Porta San Donato 2, I-40126 BOLOGNA BO, Italy, Tel: +39 051 2091727; Fax: +39 051 2091737; Email: renata.bartesaghi@unibo.it

\begin{abstract}
Down syndrome (DS), a genetic condition due to triplication of chromosome 21, is characterized by neurogenesis impairment in the major neurogenic niches of the brain. This defect largely accounts for brain hypotrophy and, hence, intellectual disability in DS. We previously found that treatment with lithium restored the number of proliferating cells in the subventricular zone (SVZ) and of new granule cells in the olfactory bulb (OB) of the Ts65Dn mouse model of DS, suggesting that treatment with lithium may be a potential tool for neurogenesis restoration in DS. The goal of the current study was to establish whether the positive effects of lithium on neurogenesis are retained after treatment cessation. To this aim, adult Ts65Dn mice aged 13 months were treated with lithium for one month, injected with BrdU during the last 3 days of treatment, and killed one month after treatment cessation. We found that in the SVZ of treated Ts65Dn mice there was an increase in the number of cells that were immunopositive for Ki-67, an endogenous marker of cycling cells and an increase in the number of surviving cells (BrdU+ cells). In contrast, the number of BrdU-positive cells in the OB, the terminal destination of neuroblasts from the SVZ, was not increased. These findings indicate that lithium induces long-lasting effects on proliferation and survival of neural progenitors in the SVZ but not in the OB, suggesting that continuous treatment may be needed in order to foster the survival of new granule neurons in the OB.
\end{abstract}

Keywords: Down syndrome; Intellectual disability; Neurogenesis; Pharmacotherapy; Lithium; Subventricular zone; Olfactory bulb

Abbreviations: BrdU: 5-Bromo-2-Deoxyuridine; DS: Down Syndrome; GRL: Granule Cell Layer; PL: Periglomerular Layer; OB: Olfactory Bulb; SGZ: Subgranular Zone; SVZ: Subventricular Zone; VZ: Ventricular Zone

\section{Introduction}

One of the major challenges of research on Down syndrome (DS) is the identification of treatments that are able to improve intellectual disability, the invariable hallmark of this genetic condition. The DS brain is characterized by a severe impairment of neurogenesis that starts at prenatal life stages and continues throughout life [1,2]. This defect largely accounts for the typical hypotrophy of the DS brain and, hence, intellectual disability. It ensues that means to improve/restore neurogenesis can be regarded as potential tools to improve intellectual disability in DS. The bulk of neurons forming the forebrain derive from the fetal ventricular zone (VZ) and, subsequently, from the subventricular zone (SVZ) of the lateral ventricle. The subgranular zone (SGZ) of the hippocampal dentate gyrus is a neurogenic niche that is specifically responsible for hippocampal neurogenesis. The SVZ and the SGZ retain proliferative capacity throughout life in all examined mammals [3]. In particular, the adult SVZ produces granule neurons destined to the olfactory bulb and the SGZ produces granule neurons destined to the granular layer of the dentate gyrus. In view of the key role of the SVZ in the generation of forebrain neurons, it appears to be particularly relevant to identify treatments that are able to increase neurogenesis in this neurogenic niche because they might be exploited in order to restore cortical neurogenesis during the most critical phases of brain development.

The Ts65Dn mouse represents the most popular model of DS and has been exploited in a number of studies aimed at discovering the molecular mechanisms underlying neurogenesis impairment in DS and at identifying possible treatments for neurogenesis restoration [4-6]. Previous studies showed that chronic treatment with lithium was able to restore the number of proliferating cells in the hippocampal dentate gyrus [7] and in the SVZ $[8,9]$ suggesting that lithium may represent a suitable therapy for correcting the neurogenesis defects that characterize DS. In the context of pharmacotherapies for DS, an important issue regards the duration of the effects of treatment. An ideal therapy should be one that not only restores the proliferation potency of neural progenitor cells but that also induces effects 
that outlast treatment cessation. Although it is unlikely that a given treatment induces completely permanent effects, if the effects of treatment outlast its discontinuation, at least for some time this may imply a schedule of periodic instead of continuous administration. With this idea in mind, the goal of the current study was to establish whether the effects exerted by lithium on neurogenesis in the SVZ extend beyond treatment cessation.

\section{Methods}

\section{Animals}

Female Ts65Dn mice carrying a partial trisomy of chromosome 16 [10] were obtained from Jackson Laboratories (Bar Harbor, ME, USA) and maintained on the original genetic background by mating them to C57BL/6JEi x C3SnHeSnJ (B6EiC3) F1 males. Animals were karyotyped as previously described [11]. A total of 16 female mice were used. The animals were group housed, had access to water and food ad libitum and lived in a room with a 12:12 hour dark/light cycle. The animal's health and comfort were veterinary controlled. Experiments were performed in accordance with the Italian and European Community law for the use of experimental animals and were approved by Bologna University Bioethical Committee. In this study, all efforts were made to minimize animal suffering and to keep to a minimum the number of animals used.

\section{Experimental protocol}

Starting from the age of 13 months, euploid $(n=4)$ and Ts65Dn $(n=4)$ females were treated with lithium, administered through the food pellets $\left(2.4 \mathrm{~g} / \mathrm{kg}\right.$ of $\left.\mathrm{Li}_{2} \mathrm{CO}_{3}\right)$ for one month. Previous evidence showed that mice treated with this dose for 3-4 weeks exhibit serum lithium levels of $0.97 \pm 0.20 \mathrm{mM}$ [12]. This is in the range of the therapeutic concentrations in humans: $0.6-1.2 \mathrm{mM}$ [13]. Age matched euploid $(n=4)$ and Ts65Dn $(n=4)$ females were used as controls. During the last three days of treatment, animals of all groups received a daily intraperitoneal injection (150 $\mu \mathrm{g} / \mathrm{g}$ body weight) of BrdU (5-bromo-2-deoxyuridine; Sigma), a marker of proliferating cells and their progeny in $0.9 \%$ $\mathrm{NaCl}$ solution. Animals were sacrificed one month after the last BrdU injection.

\section{Histological procedures}

Animals were deeply anesthetized with a massive dose of Zoletil 100 (100mg/Kg, Virbac, France) and transcardially perfused with saline, followed by $4 \%$ paraformaldehyde in $100 \mathrm{mM}$ phosphate buffer, $\mathrm{pH} 7.4$. Brains were stored in the fixative for $24 \mathrm{~h}$ and then kept in $18 \%$ sucrose in phosphate buffer for additional 24 hours. Hemispheres were cut along the midline and stored at $-80^{\circ} \mathrm{C}$. The left hemisphere and the left olfactory bulb were cut with a freezing microtome in $30-\mu \mathrm{m}$ thick coronal sections that were serially collected in antifreeze solution. For analysis in the SVZ, sections were sampled within a region that started at the rostral pole of the lateral ventricle and stretched for approximately $1200 \mu \mathrm{m}$ going in the caudal direction. The rostral and caudal borders of this region approximately correspond to $+1.18 \mathrm{~mm}$ and $+0.02 \mathrm{~mm}$ planes, respectively, of Franklin and Paxinos atlas of the mouse brain [14]. For analysis in the olfactory bulb (OB) sections were sampled from the caudal end to the middle of the OB. Each histological procedure was carried out in 1 out of 6 sections.

Immuno histochemistry. One out of six sections from the OB and SVZ was permeabilized with $0.1 \%$ Triton X-100 in PBS for $30 \mathrm{~min}$, blocked for $1 \mathrm{~h}$ in $1 \%$ BSA in $0.1 \%$ Triton X-100 and PBS. Sections were incubated overnight at $4{ }^{\circ} \mathrm{C}$ with rabbit monoclonal anti-Ki-67 antibody (Thermo Scientific Neumarkers, Fremont, CA. USA), diluted 1:200 in 0.1\% Triton X-100 in PBS, washed in $0.1 \%$ Triton X-100 in PBS for 40 min and incubated for $2 \mathrm{~h}$ with a Cy3 conjugated anti-rabbit IgG (1:200) (Jackson Immunoresearch). One out of six sections from the SVZ was processed for double-fluorescence immunohistochemistry for BrdU and GFAP. Sections were incubated overnight at $4^{\circ} \mathrm{C}$ with a primary antibody, rat monoclonal anti-BrdU antibody (AbDSerotec, Kidlington, and Oxford, UK), diluted 1:100 in 0.1\% Triton X-100 in PBS and mouse monoclonal anti-glial fibrillary acidic protein (GFAP) (Sigma) diluted $1: 400$ in $0.1 \%$ Triton $\mathrm{X}-100$ in PBS. Sections were then washed in $0.1 \%$ Triton X-100 in PBS for $40 \mathrm{~min}$ and incubated for $2 \mathrm{~h}$ with a Cy3 conjugated anti-rat IgG (1:100) (Jackson Immunoresearch) secondary fluorescent antibody, for BrdU immunohistochemistry and FITC conjugated anti-mouse IgG (1:100) (Sigma-Aldrich) for GFAP immunohistochemistry. One out of six sections from the OB were incubated overnight at $4{ }^{\circ} \mathrm{C}$ with a primary antibody, rat monoclonal anti-BrdU antibody (AbDSerotec, Kidlington, Oxford, UK), diluted $1: 100$ in $0.1 \%$ Triton X-100 in PBS. Sections were then washed in $0.1 \%$ Triton X-100 in PBS and incubated for $2 \mathrm{~h}$ with a Cy3 conjugated anti-rat IgG (1:100; Jackson Immunoresearch) secondary fluorescent antibody, for BrdU immunohistochemistry. Fluorescent images were taken with an Eclipse TE 2000-S microscope (Nikon, Tokyo, Japan) equipped with an Axio Cam MRm (Zeiss, Oberkochen, Germany) digital camera or with a Leica TCS confocal microscope (Leica Microsystems, Wetzlar, Germany).

\section{Measurements}

Number of Ki-67-positive cells, of BrdU-positive cells and of cells co-labeled with BrdU and GFAP in the SVZ. In the series of sections processed for Ki-67 immunohistochemistry, all Ki67-positive cells located along the dorsal and lateral wall of the ventricle were counted, as previously described [15]. In the series of sections processed for double fluorescence immuno histochemistry for BrdU and GFAP, all BrdU-positive cells and cells that co-expressed BrdU and GFAP (BrdU+/GFAP+ cells) were counted along the dorsal and lateral wall of the ventricle. The number of GFAP-negative cells (BrdU+/GFAP- cells) was obtained by subtracting from the total number of BrdU-positive cells the number of cells that co-exspressed BrdU and GFAP. The total number of Ki-67-positive cells, BrdU-positive cells; BrdU+/ $\mathrm{GFAP}+$ cells, and BrdU+GFAP- cells was estimated by multiplying the number counted in the series of sections by the inverse of the section sampling fraction $(s s f=1 / 6)$. Number of BrdU-positive 


\section{Open Access Journal of Neurology \& Neurosurgery}

cells in the OB. In the $\mathrm{OB}$ cells were counted in the granule cell layer and in the periglomerular layer, separately. The total number of BrdU-positive cells was estimated by multiplying the number counted in the series of sampled sections by the inverse of the section sampling fraction $(\mathrm{ssf}=1 / 6)$.

\section{Statistical analysis}

Results are presented as mean \pm standard error of the mean (SE). Statistical testing was performed using a two-way analysis of variance (ANOVA) with genotype (euploid and Ts65Dn) and treatment (standard chow, standard chow+lithium) as fixed factors and mouse as random factor followed by Fisher LSD post hoc test. A probability level of $p<0.05$ was considered to be statistically significant.

\section{Results}

\section{Long-term effects of lithium on the pool of proliferating cells in the SVZ of Ts65Dn mice}

In the current study, mice aged 13 months were treated with lithium for one month and the effects of treatment on proliferation potency in the SVZ were examined one month after treatment cessation, i.e., when mice were 15 months old. To this purpose, brain sections were subjected to immunohistochemistry for Ki67, an endogenous marker expressed by cells during all phases of the cell cycle. Consequently, the number of Ki-67-positive cells can be taken as indicative of the size of the population of actively dividing cells in the region of interest.
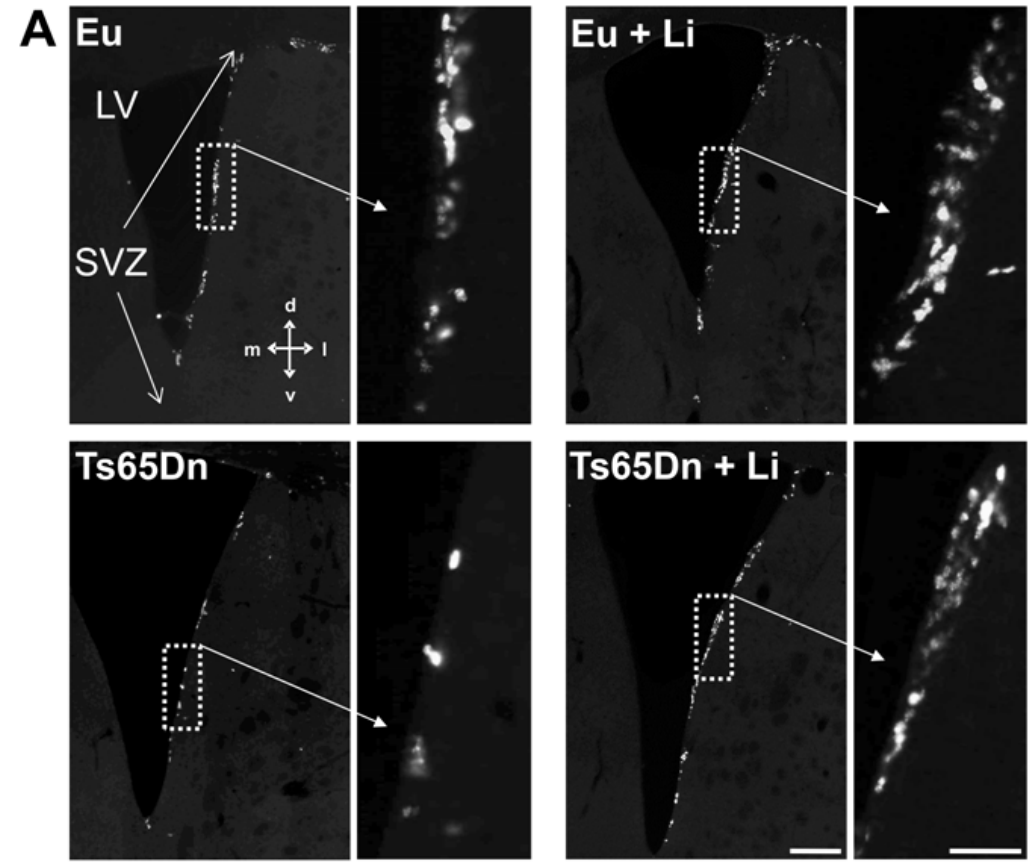

B
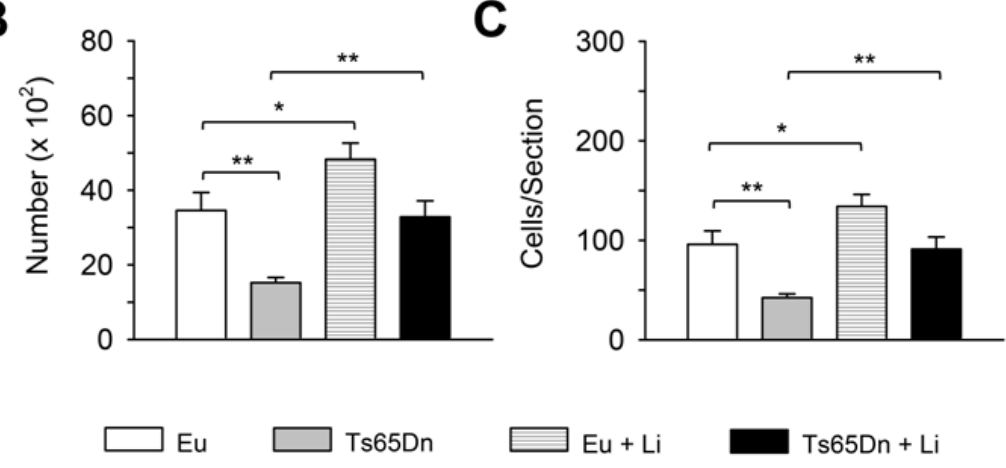

Figure 1: Long-term effect of lithium on proliferation potency in the SVZ of Ts65Dn and euploid mice.

A: Examples of coronal sections processed for fluorescence Ki-67 immunohistochemistry from the SVZ of untreated euploid and Ts65Dn mice, and of euploid and Ts65Dn mice treated with lithium for one month starting from 13 months of age and killed one month after treatment cessation, at the age of 15 months. During the last three days of treatment, animals received a daily intraperitoneal injection of BrdU. The dashed rectangles indicate the region reported at higher magnification on the right of each panel. Calibration $=200 \mu \mathrm{m}$ (low magnification images) and $=50 \mu \mathrm{m}$ (high magnification images). B,C: Total number of Ki-67-positive cells (B) and mean number of Ki-67-positive cells per section (C) in the SVZ of treated and untreated euploid and Ts65Dn mice. Values (mean \pm SE) represent totals for one hemisphere. ${ }^{*} p<0.05$ ; * $\mathrm{p}<0.01$ (Fisher LSD test after two-way ANOVA).

Abbreviations: d: dorsal; Eu: Euploid; I: lateral; Li: lithium; LV: Lateral Ventricle; m: Medial; SVZ: Subventricular Zone; v: ventral. 
Confirming previous evidence [8], Ts65Dn mice had fewer Ki-67-positive cells (-56\%) in comparison with euploid mice (Figure 1A-1C). Treated Ts65Dn mice underwent a large increase $(+100 \%)$ in the number of Ki-67-positive cells in comparison with their untreated counterparts (Figure 1A-1C). A comparison between treated Ts65Dn mice and untreated euploid mice showed no differences in the number of Ki-67-positive cells (Fig. $1 \mathrm{~A}-\mathrm{C}$ ), indicating that treatment had fully restored the number of proliferating cells in the SVZ. In euploid mice treatment caused an increase in the number of Ki-67-positive cells that became larger $(+40 \%)$ in comparison with the number of Ki-67-positive cells of untreated euploid mice (Figure 1A-1C). A previous study showed that at the end of a one-month treatment with lithium, Ts65Dn mice underwent restoration of the number of Ki-67positive cells [8].The current finding that in treated Ts65Dn mice the number of Ki-67-positive cells was still restored one month after treatment cessation, indicates that treatment with lithium

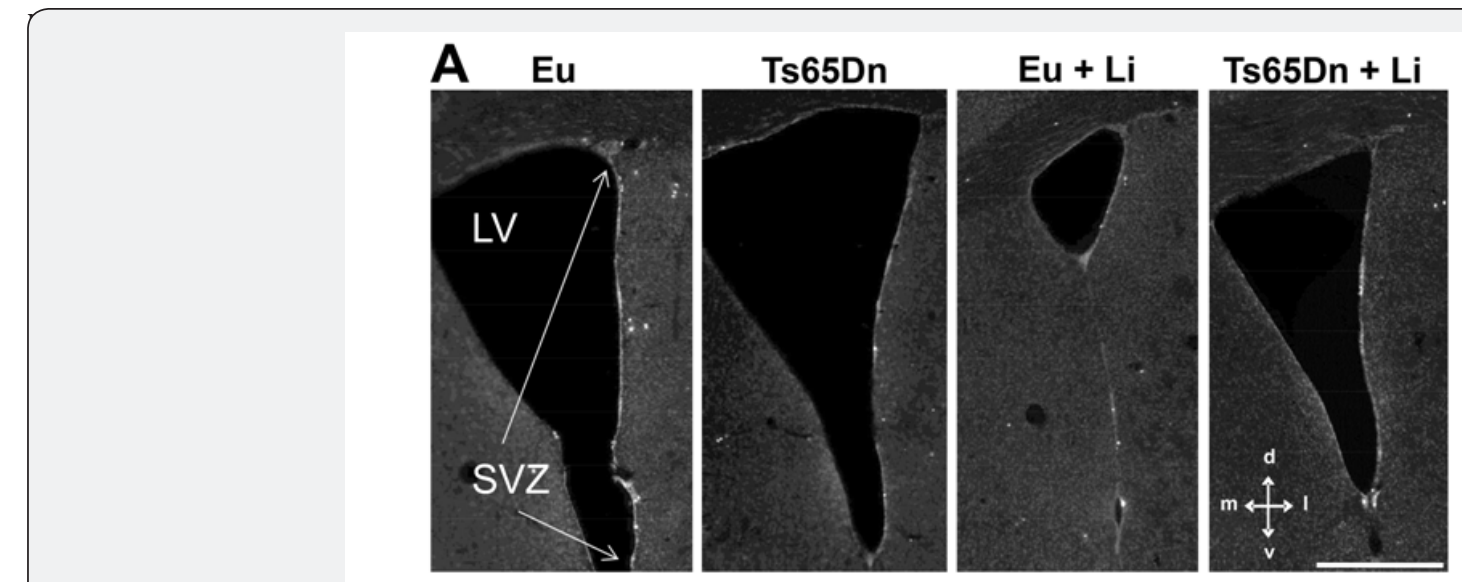

Figure 2(A): Long-term effect of lithium on cell survival in the SVZ of Ts65Dn and euploid mice.

A: Examples of coronal sections processed for fluorescence BrdU immunohistochemistry from the SVZ of untreated euploid and Ts65Dn mice, and of euploid and Ts65Dn mice treated with lithium for one month starting from 13 months of age and killed one month after treatment cessation, at the age of 15 months. During the last three days of treatment, animals received a daily intraperitoneal injection of BrdU. Calibration $=500 \mu \mathrm{m}$.

\section{Long-term effects of lithium on cell survival in the SVZ of Ts65Dn mice}

BrdU, a thymidine analogue that is incorporated by cells during the S-phase of the cell cycle, can be used to evaluate the proliferation rate of the population of interest as well as to follow the fate of the cells that have incorporated the marker at selected time points after BrdU injection. We found that very few BrdU-positive cells were present in the SVZ one month after BrdU injection (Figure 2A). The total number of BrdU-positive cells was approximately 250 in untreated euploid mice and approximately 150 in untreated Ts65Dn mice. We previously found that, $24 \mathrm{~h}$ after BrdU administration, the number of BrdUpositive cells in the SVZ was approximately 3500 in untreated euploid mice and 2000 in untreated Ts65Dn mice [9]. A comparison of these figures indicates that the number of BrdUpositive cells present in the SVZ one month after BrdU injection corresponds to approximately $7.0-7.5 \%$ of the originally labeled population. This reduction is not surprising considering that the new neurons born in the SVZ leave their site of origin to reach their final destination, the olfactory bulb, and that some of the proliferating cells are bound to die.

A comparison of the number of BrdU-positive cells in untreated mice showed that Ts65Dn mice had fewer BrdU- positive cells compared to euploid mice (Figure 2A \& 2B), which is consistent with previous observations of reduced neurogenesis in the SVZ of Ts65Dn mice [8,9]. Treated Ts65Dn mice, however, had a larger number of BrdU-positive cells in comparison with untreated Ts65Dn mice and their number of BrdU-positive cells was similar to that of untreated euploid mice. In previous studies, we found that one month of treatment with lithium increased the number of BrdU-positive cells in the SVZ of Ts65Dn mice to values similar to those of euploid mice $[8,9]$. The current finding that Ts65Dn mice still had more BrdU-positive cells in the SVZ one month after treatment cessation indicates a long-term effect of lithium on cell survival in the SVZ.

It is well-established that the stem cells of the SVZ are cells that express the astrocytic marker GFAP [16]. In sections subjected to double-fluorescence immunohistochemistry for BrdU and GFAP we evaluated the number of cells that were BrdU+/GFAP+ and the number of cells that were BrdU+/GFAP-. We found that untreated Ts65Dn mice had fewer cells that were double labeled for BrdU and GFAP in comparison with untreated euploid mice, although the difference did not reach statistical significance (Figure 2C). Treated Ts65Dn mice underwent a large and significant increase in the number of cells that were double-labeled for BrdU and GFAP that became similar to the number of untreated euploid mice (Figure 2C). An evaluation of 


\section{Open Access Journal of Neurology \& Neurosurgery}

cells that were BrdU-positive but did not express GFAP (BrdU+/ GFAP-) showed that untreated Ts65Dn mice had fewer BrdU+/ GFAP- cells in comparison with untreated euploid mice (Figure 2D). In treated Ts65Dn mice there was an increase in the number of BrdU+/GFAP- cells that became similar to that of untreated euploidmice (Figure 2D). The stem cells of the SVZ (type B cells) give origin to transit amplifying cells (type $\mathrm{C}$ cells) which, in turn, generate migrating neuroblasts (type A cells) [16]. These data suggest a long-term effect of lithium on the survival of different cell types in the SVZ. In euploid mice, treatment with lithium had no long-term effect on the total number of surviving cells neither in the SVZ (Figure 2B) nor on the number of GFAPpositive (Figure 2C) or GFAP-negative (Figure 2D) cells.
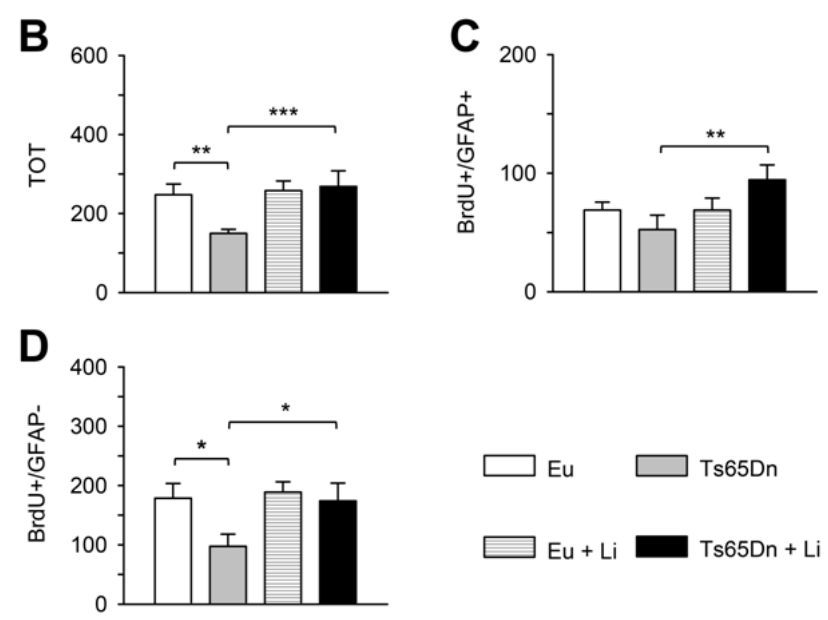

Figure 2(B,C,D): Long-term effect of lithium on cell survival in the SVZ of Ts65Dn and euploid mice.

B-D: Total number of BrdU+ cells (B), BrdU+/GFAP+ cells (C) and of BrdU+/GFAP- cells (D) in the SVZ of treated and untreated euploid and Ts65Dn mice. Values (mean \pm SE) represent totals for one hemisphere. ${ }^{*} p<0.05$; ${ }^{* *} p<0.01 ;{ }^{* * *} p<0.001$ (Fisher LSD test after two-way ANOVA). Abbreviations: d: Dorsal; EU:: Euploid; L: lateral; Li: Lithium; Iv: Lateral Ventricle; m: Medial; SVZ: Subventricular Zone; v: Ventral.

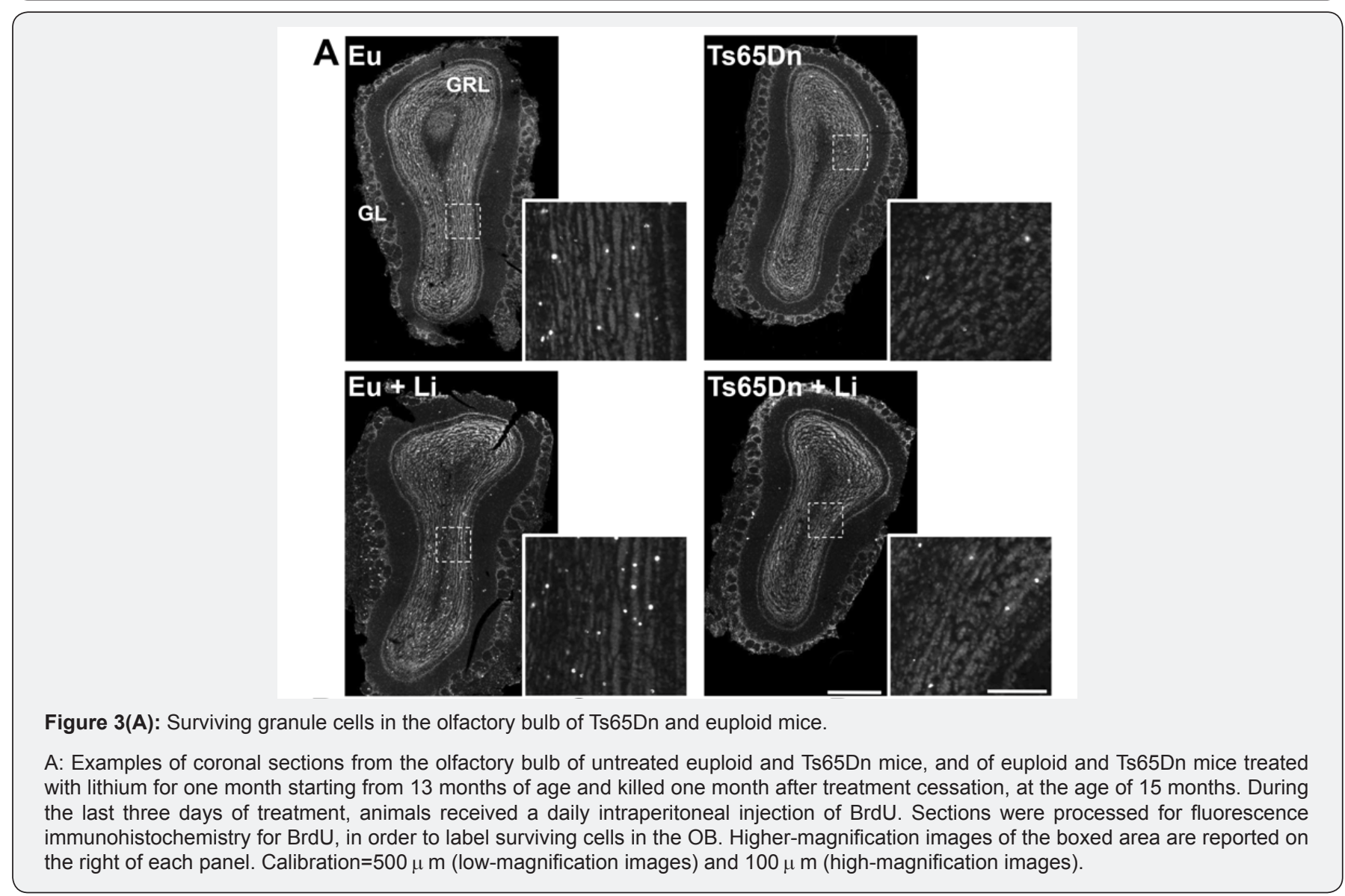



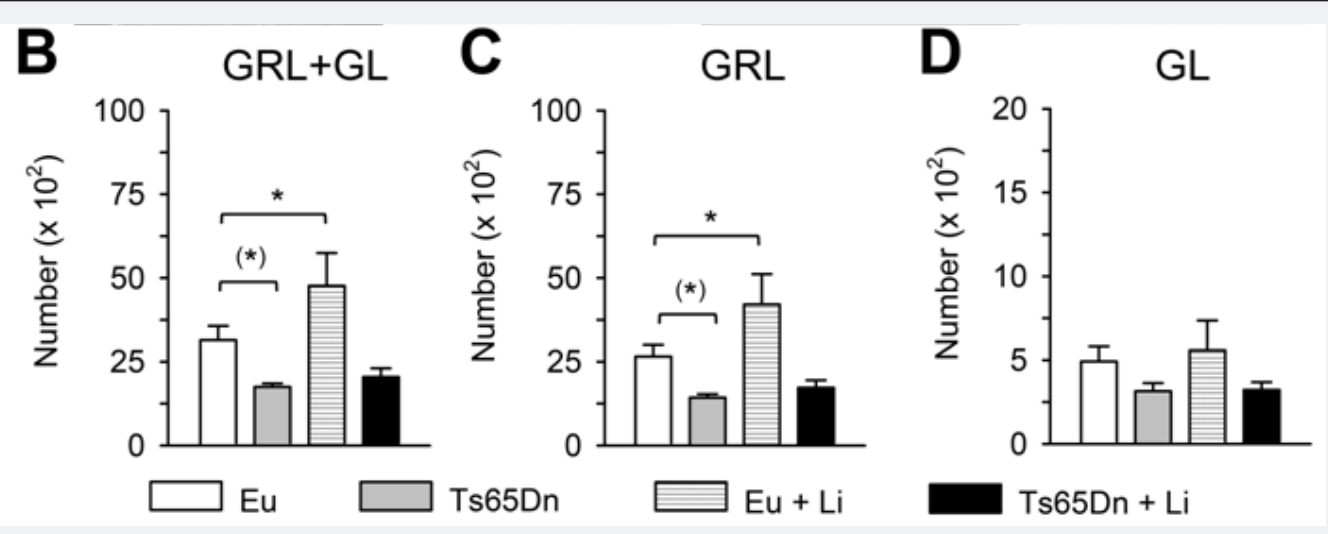

Figure 3(B,C,D): Surviving granule cells in the olfactory bulb of Ts65Dn and euploid mice.

B-D: Number of BrdU-positive cells in the granule cell layer plus periglomerular layer $(B)$, in the granule cell layer $(C)$, and in the glomerular layer (D). Values (mean \pm SE) represent totals for one olfactory bulb. $\left(^{*}\right) p<0.06 ; p<0.05$ (Fisher LSD test after two-way ANOVA). Abbreviations: Eu: Euploid; GL: Peri Glomerular Layer; GRL: Granule Cell Layer; Li: lithium.

\section{Long-term effects of lithium on the number of new granule cells in the olfactory bulb of Ts65Dn mice}

Most of the cells that have migrated from the SVZ to the OB differentiate into granule cells in the granule cell layer (GRL) and fewer cells differentiate into periglomerular cells in the periglomerular layer (GL) [17]. Accordingly, we found that both in euploid and Ts65Dn mice most of the BrdU-positive cells were located in the granule cell layer of the $\mathrm{OB}$ and the remaining cells were located in the glomerular layer (Figure 3A-D). A comparison between untreated euploid and Ts65Dn mice showed that in the $\mathrm{OB}$ of the latter there were fewer BrdU-positive cells (-44\%); (Figure 3A \& 3B), consistently with the reduced proliferation potency in the SVZ found here (Figure 1) and in previous studies $[8,9,18]$. The separate evaluation of BrdU-positive cells in the different layers of the OB showed that Ts65Dn mice had fewer new granule cells, both in the granule cell layer (-46\%); (Figure $3 \mathrm{C}$ ) and periglomerular layer (-32\%); (Figure 3D), although in the periglomerular layer the difference was not statistically significant. A comparison of treated and untreated Ts65Dn mice showed no effect of treatment on the total number of BrdUpositive cells (Figure 3B) or on the number of BrdU-positive cells in the granular layer (Figure 3C) and periglomerular layer Table 1: Body weight of the experimental groups.
(Figure 3D). Treated euploid mice showed a larger total number of BrdU-positive cells in the GRL plus GL and more BrdU-positive cells in the granular layer in comparison with their untreated counterparts (Figure 3B-3D).

\section{Effect of lithium on body weight}

Untreated Ts65Dn mice had a reduced body weight in comparison with untreated euploid mice (Table 1), which reflects a typical phenotypic feature of the Ts65Dn mouse model $[8,9,19]$. A comparison of treated and untreated mice showed that treated euploid mice underwent a body weight reduction in comparison with their untreated counterparts. In contrast, no weight differences were found between treated and untreated Ts65Dn mice (Table 1). In patients on chronic lithium therapy, signs of toxicity can occur at doses close to therapeutic levels [20]. We previously found no weight differences between treated and untreated Ts65Dn mice at the end of one month of treatment with lithium [9]. The current finding that treated Ts65Dn mice did not undergo a body weight reduction in comparison with their untreated counterparts, suggests the absence of long-term adverse effects of treatment with lithium on animal general health.

\begin{tabular}{|c|c|c|c|c|c|c|c|c|c|c|}
\hline & & Mean & & ES & & & Mean & ES & p \\
\hline Eu & & 41.25 & \pm & 2.42 & & Eu+Li & 32.72 & \pm & 3.15 & 0.01 \\
\hline Ts65Dn & & 27.65 & \pm & 1.55 & & Ts65Dn+Li & 26.17 & \pm & 0.48 & n.s \\
\hline & $\mathrm{p}=$ & 0.001 & & & & & 0.05 & & & \\
\hline
\end{tabular}

Note: Body weight (mean \pm SE) in grams of untreated euploid $(n=4)$ and Ts65Dn mice $(n=4)$ and euploid $(n=4)$ and Ts65Dn $(n=4)$ mice treated with lithium. The $p$ values refer to Fisher LSD test after ANOVA. n.s.=not significant.

\section{Discussion}

\section{Treatment with lithium leaves an enduring trace in the SVZ of Ts65Dn mice}

Previous studies showed that lithium restores the defective number of proliferating cells in the dentate gyrus [7] and in the SVZ of Ts65Dn mice $[8,9]$. An important issue in the field of pharmacotherapies for DS and, more generally, for pathologies characterized by proliferation deficiency, regards whether the effects of treatment are retained after treatment cessation. While no information is available for the dentate gyrus, the current study provides novel evidence that treatment with lithium leaves an enduring, positive impact on proliferation potency in the SVZ of Ts65Dn mice. The germinal niche of the SVZ is mainly 
formed by stem cells $(\sim 23 \%)$, transit amplifying cells $(\sim 11 \%)$, neuroblasts $(\sim 33 \%)$ and ependymal cells $(\sim 28 \%)$ [16]. Type B cells produce transit amplifying cells that, in turn, produce neuroblasts. Based on thymidine incorporation, all these cell types have been shown to have a replicative capacity [16]. In the current study, we injected mice with BrdU during the last three days of treatment with lithium and examined the effects of treatment on the number of BrdU-positive cells that were still present in the SVZ one month after treatment cessation.

The number of BrdU-positive cells present in the SVZ one month after BrdU injection was expected to undergo a reduction because i) neuroblasts leave the SVZ to reach the OB, ii) some of the originally labeled cells may die, iii) BrdU may become undetectable due to repeated cell divisions. Accordingly, we found that approximately $7.0-7.5 \%$ of the originally labeled cells were present in the SVZ one month after BrdU injection. Importantly, Ts65Dn mice treated with lithium still had more BrdU-positive cells in comparison with their untreated counterparts, indicating an enduring effect of treatment on cell survival. An evaluation of the number of BrdU+/GFAP+ cells and BrdU+/GFAP- cells showed that in treated Ts65Dn mice both cell populations were increased in comparison with untreated Ts65Dn mice, suggesting that lithium exerts a generalized increase in the survival rate of different cell types. Although it cannot be ruled out that some of the BrdU+/GFAP+ surviving cells were cells that had acquired an astrocytic phenotype, it seems reasonable to assume that some of the BrdU+/GFAP+ cells were stem cells. Recent evidence that chronic treatment with lithium specifically targets stem cells in the hippocampus of the adult mouse [21] and, possibly, targets striatal neural stem cells [22] is consistent with the possibility that stem cells of the SVZ are included in the populations of cells whose survival is positively affected by lithium.

\section{Treatment with lithium does not induce a long-term increase in the number of granule cells in the olfactory bulb}

The OB represents the final destination of neuroblasts born in the SVZ. In order to establish whether the increase in proliferation rate previously observed in the SVZ of Ts65Dn mice [9] translated into a long-term increase in the number of granule neurons added to the $\mathrm{OB}$, we evaluated the number of BrdUpositive cells in the $\mathrm{OB}$ one month after treatment cessation. Unlike in the SVZ, in the OB of Ts65Dn mice treatment did not lead to an increase in the number of surviving cells. This finding was unexpected, considering that immediately after one month of treatment with lithium the number of new granule neurons in the OB of Ts65Dn mice underwent an increase [9]. Taken together, the present and previous findings indicate that lithium can increase the number of new granule neurons added to the $\mathrm{OB}$ but that this increase is not retained after discontinuation of treatment. Altogether, this evidence suggests that a continuous treatment with lithium may be necessary for the long-lasting integration of the new granule neurons in the OB. In agreement with our findings regarding the $\mathrm{OB}$, controversial effects have been reported regarding the effects of lithium on neuronal differentiation/survival in the dentate gyrus. While some studies show that lithium enhances acquisition of a neuronal fate [23], other reports indicate that the percentage of NeuN-positive neurons remains unchanged [12] and that, although lithium enhances quiescent neural progenitor-turnover in the mouse hippocampus, this effect does not translate into an increased number of neurons [21].

\section{Conclusion}

Taken together, our results show that lithium has proproliferative effects in the SVZ of Ts65Dn mice and that these effects are retained after treatment cessation. The pro-proliferative effects of lithium in the SVZ are due to the enhancement of both proliferation rate and cell survival. On the contrary, the addition of new granule neurons in the OB appears to be ephemeral and their permanent integration in the $\mathrm{OB}$ circuits is likely to require the continuous presence of lithium. The mechanisms whereby lithium enhances neurogenesis and leaves an enduring trace in the SVZ of Ts65Dn mice remain to be established. From the current findings, it appears that chronic treatment with lithium positively impacts on molecular pathways that are involved in neurogenesis, and that are possibly altered in DS, and that these readjustments are retained with time. Interestingly, chronic treatment leads to specific accumulation of lithium in neurogenic regions which may be relevant for the induction and maintenance of long-term effects on neurogenesis [24].

Although the SVZ and the SGZ of the dentate gyrus represent the major neurogenic niches of the postnatal brain, neurogenesis has also been shown to take place in other brain areas such as the amygdala, piriform cortex, inferior temporal cortex, neocortex, striatum, hypothalamus and midbrain [25-29]. Individuals with DS exhibit, in addition to intellectual disability, various behavioral alterations [2,30-32] in which these brain regions are likely to be involved. It remains to be established whether lithium also exerts pro-proliferative effects in brain regions outside the SVZ and SGZ of the dentate gyrus. If so, treatment with lithium may be envisaged as a potential means by which to improve various aspects of brain function in the adult DS brain.

\section{Acknowledgment}

This work was supported by grants to R. B. from "Fondation Jerome Lejeune", France, "Fondazione Generali e Assicurazione Generali", Italy and "Fondazione del Monte", Italy. The assistance of Melissa Stott in the revision of the language and the technical assistance of Mr. Francesco Campisi and Mr. Massimo Verdosci are gratefully acknowledged.

\section{References}

1. Stagni F, Giacomini A, Emili M, Guidi S, Bartesaghi R (2018) Neurogenesis impairment: An early developmental defect in Down syndrome. Free radic biol Med 114: 15-32. 


\section{Open Access Journal of Neurology \& Neurosurgery}

2. Dierssen M (2012) Down syndrome: the brain in trisomic mode. Nat Rev Neurosci 13(12): 844-858.

3. Gage FH (2000) Mammalian neural stem cells. Science 287(5457): 1433-1438.

4. Stagni F, Giacomini A, Guidi S, Ciani E, Bartesaghi R (2015) Timing of therapies for Down syndrome: the sooner, the better. Front Behavioral Neurosci 9: 265.

5. Gardiner KJ (2014) Pharmacological approaches to improving cognitive function in Down syndrome: current status and considerations. Drug Des Devel Ther 9: 103-125.

6. Costa AC (2011) On the promise of pharmacotherapies targeted at cognitive and neurodegenerative components of Down syndrome. Dev Neurosci 33(5): 414-427.

7. Contestabile A, Greco B, Ghezzi D, Tucci V, Benfenati F, et al. (2013) Lithium rescues synaptic plasticity and memory in Down syndrome mice. J Clin Invest 123(1): 348-361.

8. Bianchi P, Ciani E, Contestabile A, Guidi S, Bartesaghi R (2010) Lithium Restores Neurogenesis in the Subventricular Zone of the Ts65Dn Mouse, a Model for Down Syndrome. Brain Pathol 20(1): 106-118.

9. Guidi S, Bianchi P, Stagni F, Giacomini A, Emili M, et al. (2016) Lithium restores age related olfactory Impairment in the Ts65Dn Mouse Model of Down Syndrome. CNS Neurol Disord Drug Targets 16(7): 812-819.

10. Reeves RH, Irving NG, Moran TH, Wohn A, Kitt C, et al. (1995) A mouse model for Down syndrome exhibits learning and behaviour deficits. Nat Genet 11(2): 177-184.

11. Reinholdt LG, Ding Y, Gilbert GJ, Czechanski A, Solzak JP, et al. (2011) Molecular characterization of the translocation breakpoints in the Down syndrome mouse model Ts65Dn. Mamm Genome 22(11-12): 685-691.

12. Chen G, Rajkowska G, Du F, Seraji-Bozorgzad N, Manji HK (2000) Enhancement of hippocampal neurogenesis by lithium. J Neurochem 75(4): 1729-1734.

13. Grandjean EM, Aubry J-M (2009) Lithium: updated human knowledge using an evidence-based approach. Part II: Clinical pharmacology and therapeutic monitoring. CNS drugs 23(4): 331-349.

14. Franklin KBJ, Paxinos G (1997) The mouse brain in stereotaxic coordinates. Academic Press Publishing Company, Massachusetts, USA

15. Doetsch F, Caille I, Lim DA, Garcia-Verdugo JM, Alvarez-Buylla A (1999) Subventricular zone astrocytes are neural stem cells in the adult mammalian brain. Cell 97(6): 703-716.

16. Whitman MC, Greer CA (2009) Adult neurogenesis and the olfactory system. Prog Neurobiol 89(2): 162-175.

17. Bianchi P, Bettini S, Guidi S, Ciani E, Trazzi S, et al. (2014) Age-related impairment of olfactory bulb neurogenesis in the Ts65Dn mouse model of Down syndrome. Exp Neurol 251: 1-11.

This work is licensed under Creative

Commons Attribution 4.0 Licens

DOI: 10.19080/OAJNN.2018.07.555718
18. Belichenko PV, Masliah E, Kleschevnikov AM, Villar AJ, Epstein CJ, et al. (2004) Synaptic structural abnormalities in the Ts65Dn mouse model of Down Syndrome. J Comp Neurol 480(3): 281-298.

19. Aral H, Vecchio-Sadus A (2008) Toxicity of lithium to humans and the environment-a literature review. Ecotoxicology and environmental safety 70: 349-356.

20. Kara N, Narayanan S, Belmaker RH, Einat H, Vaidya VA, et al. (2015) Chronic lithium treatment enhances the number of quiescent neural progenitors but not the number of dcx-positive immature neurons. Int J Neuropsychopharmacol 18(7): 003.

21. Senatorov VV, Ren M, Kanai H, Wei H, Chuang DM (2004) Short-term lithium treatment promotes neuronal survival and proliferation in rat striatum infused with quinolinic acid, an excitotoxic model of Huntington's disease. Mol Psychiatry 9(4): 371-385.

22. Kim JS, Chang MY, Yu IT, Kim JH, Lee SH, et al. (2004) Lithium selectively increases neuronal differentiation of hippocampal neural progenitor cells both in vitro and in vivo. J Neurochem 89(2): 324-336.

23. Zanni G, Michno W, Di Martino E, Tjärnlund-Wolf A, Pettersson J, et al. (2017) Lithium accumulates in neurogenic brain regions as revealed by high resolution ion imaging. Scientific Reports 7: 40726.

24. Bernier PJ, Bedard A, Vinet J, Levesque M, Parent A (2002) Newly generated neurons in the amygdala and adjoining cortex of adult primates. Proc Natl Acad Sci U S A 99(17): 11464-11469.

25. Cameron HA, Dayer AG (2008) New interneurons in the adult neocortex: small, sparse, but significant? Biol Psychiatry 63(7): 650655.

26. Fowler CD, Liu Y, Wang Z (2008) Estrogen and adult neurogenesis in the amygdala and hypothalamus. Brain Res Rev 57(2): 342-351.

27. Kokoeva MV, Yin H, Flier JS (2005) Neurogenesis in the hypothalamus of adult mice: potential role in energy balance. Science $310(5748)$ : 679-683.

28. Farzanehfar P (2018) Comparative review of adult midbrain and striatum neurogenesis with classical neurogenesis. Neurosci Res S0168-0102(17): 30625-30629.

29. Rachidi M, Lopes C (2008) Mental retardation and associated neurological dysfunctions in Down syndrome: a consequence of dysregulation in critical chromosome 21 genes and associated molecular pathways. Eur J Paediatr Neurol 12(3): 168-182.

30. Chapman RS, Hesketh LJ (2000) Behavioral phenotype of individuals with Down syndrome. Ment Retard Dev Disabil Res Rev 6(2): 84-95.

31. Vicari S (2004) Memory development and intellectual disabilities. Acta Paediatr Suppl 93(445): 60-63.

32. Vicari S (2006) Motor development and neuropsychological patterns in persons with Down syndrome. Behav Genet 36(3): 355-364.

\section{Your next submission with Juniper Publishers} will reach you the below assets

- Quality Editorial service

- Swift Peer Review

- Reprints availability

- E-prints Service

- Manuscript Podcast for convenient understanding

- Global attainment for your research

- Manuscript accessibility in different formats

( Pdf, E-pub, Full Text, Audio)

- Unceasing customer service

Track the below URL for one-step submission

https://juniperpublishers.com/online-submission.php 